\title{
Did ya take something?
}

\author{
Cindy A. Buckmaster, PhD, CMAR, RLATG
}

I have a confession to make: some of you may think this is a little crazy, but the sound of these words makes my blood boil! I'll be with family or out with friends, and it won't be long before someone among us or around us starts complaining about some sort of ailment he or she is experiencing and someone else responds instantly with, "Did ya take something?" It infuriates me most when the complaints are relatively minor: "My back is stiff...Did ya take something?...I'm bloated...Did ya take something?...I didn't sleep well...Did ya take something?...I woke up with a headache...Did ya take something?...I have the sniffles today...Did ya take something?"

As soon as I hear it, my eyes sharpen, my lips tighten and my ears get hot! I have to draw on my new-age, woman-over- 40 coping skills and 'focus on my breath' to keep myself from blasting into orbit about something that everyone around me would consider ridiculous. But is it ridiculous? What is it about this response that makes me so angry? Is it the phrase itself? No! It's the way it spills from their lips, autonomically, like the breath they exhaled when they said it. It's the tone of entitlement in their voices that comes from living a life filled with feelgood conveniences that are expected and taken for granted. And more than anything else, it's my disgust with the fact that most of these people have no idea how all of these conveniences came to exist in the first place. They don't wonder about the true costs of their never-ending demands for comfort and well-being, and they're perfectly willing to believe that animals aren't still necessary to meet them. They live in a fantasy world where treatments and cures come from doctors and drug companies, not science, and they can't imagine how animals play a role in any of this. These people, like millions of other Americans, are disconnected from the reality of biomedical progress and accept no accountability for the animal lives lost for their benefit. So, is this what makes my blood boil? No. I think it's deeper than that.

\section{It's still fairly uncommon \\ to read or hear about the contributions of animals in} the media's announcements of new treatments and cures. These miracles just seem to pop up when we need them.

I'm not sure I should expect people in the mainstream public to behave any differently, actually. It's still fairly uncommon to read or hear about the contributions of animals in the media's announcements of new treatments and cures. These miracles just seem to pop up when we need them, and there is rarely any mention of the decades of basic research with animal models that led to their development. The news is celebrated and, for a brief moment, most of us feel grateful to the people who made it possible. The focus then shifts to the here and now. When will this new therapy be available? Where can we get it and how much will it cost? No one considers the thousands of animals who died for this particular miracle. They didn't make the story. And why is that? Because someone behind the press release to the media decided that it wouldn't be good for public relations if they told the truth.

Most research enterprises avoid full disclosure for two reasons. We fear attacks from animal rights fanatics; and we fear the response of consumers who dislike the fact that animals are still necessary for the biomedical progress they demand. So, we downplay the contributions of millions of animals and, in so doing, enable millions of Americans to live in the fantasy world I described above. Perhaps this is partly why the organization People for the Ethical Treatment of Animals felt empowered to submit a paper to the Journal of Medical Ethics recently, implying that we have lied about our intention to reduce animal numbers in research. It wouldn't occur to most Americans that the explosive increase in treatments and cures that they've enjoyed over the past decade coincided with the increased use of mice reported. Not surprisingly, the authors of this paper failed to point that out. Why would they? The animal rights agenda thrives on partial truths to manipulate the uninformed, and our fear of sharing the complete truth with the American public has allowed them to do so for decades. How long are we going to continue hiding and fooling ourselves? When are we going to rescue the American people from their fantasy world and hold them accountable for the true costs of their demands? We have to stop sugarcoating the truth when we communicate with the media, and everyone else for that matter. The real truth is that research with animals is still necessary for biomedical progress. The real truth is that our community honors these animals and provides them with exceptional and compassionate care. The real truth is that millions of animals still die so we can 'take something'. Failing to acknowledge them for this is disrespectful and ungrateful, and that is what really makes my blood boil! 